\title{
CZECH BOATMEN EMPLOYED IN THE NETHERLANDS: UNUSUAL INCOME TAXATION AND AN UNRESPONSIVE PUBLIC POLICY
}

\author{
Jan MERTL \\ doc. Ing., Ph.D., Department of finance, University of Finance and \\ Administration, Czech Republic \\ E-mail: jan.mertl@outlook.com
}

\section{Yvona LEGIERSKÁ}

Ing., Ph.D., Department of finance, University of Finance and Administration, Czech Republic

E-mail: yvona.legierska@seznam.cz

\begin{abstract}
International treaties on the limitation of double taxation have set out rules which regulate in which country tax should be paid if taxpayers receive earnings from abroad. This article deals with the place of taxation for gross wages. These taxes are predominantly paid in the country, where the employer has got its registered office. Some rare exceptions exist, however, where the employee reports and pays tax in the country of their origin, i.e. where they have their domicile. This applies to the earnings from employment of Czech boatmen employed in the Kingdom of the Netherlands based on a treaty concluded with the former Czechoslovakia in 1974. The Financial Administration of the Czech Republic has placed many boatmen and their families in a highly unfavourable social situation as a result of demands for the repayment of income tax on earnings from employment, including sanctions, despite the option of a refund of any tax paid in the Netherlands. The objective of this article is to point to a possible conceptual solution for such exceptions.
\end{abstract}

Keywords: income tax, earnings from employment, tax domicile, treaty on the limitation of double taxation, Czech boatmen.

JEL classification: H24, H55. 


\section{Introduction}

Countries exercise their right to tax according to their legal system. If a taxpayer is subject to taxation in more than one jurisdiction in respect of their foreign income, they are generally taxed more heavily than similar transactions conducted only in the tax jurisdiction where they are tax resident. As a result of a conflict of taxing rights, such a taxpayer is often subject to double taxation. The solution to this conflict is the conclusion of international treaties to avoid double taxation. They are also intended to prevent some income from not being taxed at all. Legal and economic aspects of these treaties as well as the international taxation of income and capital is subject to in-depth law and economic analyses (Becker, Reimer, Rust \& Vogel, 2015).

This article deals with the area of the taxation of earnings from employment which Czech citizens receive from abroad. It generally applies to any such earnings that are taxed in the country where the employer has its registered office. There are, however, rare exceptions where the payers of tax on earnings from employment are employees working outside the territory of Czech Republic on board ships or planes in international transport, but within the country of their residence. This also concerns the treaty with the Kingdom of the Netherlands, which was concluded in 1974, when Czechoslovakia existed. The Czech Republic only began applying the appropriate article of the treaty in September 2016, when it received a list of hundreds of such Czech citizens employed as boatmen with companies in the Netherlands based on the international exchange of information between tax authorities.

The aim of this paper is to point to the inflexibility and unresponsiveness of Czech tax administration when resolving these situations and to evaluate the socio-political and tax-policy contexts of the problem and the possible conceptual solutions to such exceptions which arise from them.

The results of the research and recommendations are based on the authors' own experience in tax theory and practice, socioeconomic analysis of the boatmen's specific social situation and taxation duties, as well as on the accommodating approach of the Slovak political representation and the legal system of the Slovak Republic, which found itself in an analogous situation to the Czech Republic after the division of Czechoslovakia in 1993. The basis for the use of the Slovak experience was a published article about different approaches to general anti-avoidance rules and their feasibility in tax treaties situations (Koroncziová \& Kacaljak, 2018) as well as personal consultations with academic staff at the University of Economics in Bratislava.

From a methodological point of view, the article proceeds from an analysis of the secondary information sources and the synthesis of factual accounts 
concerning the socio-economic and legal position of the affected individuals, i.e. the boatmen. This involves an empirical case study based on an analysis of the provisions of the international treaty, an economic analysis of the international taxation of the income of natural persons and an analysis of the processes of public policy, which are failing in this case from the point of view of the boatmen. The analytical part of the article further points to the fiscal and personal impacts on the individual subjects and to the basic quantitative definition of the problem in question.

\section{The sense and controversies of treaties on the limitation of double taxation}

International double taxation of income and wealth arises as a result of a conflict between two or more tax laws of different countries (the country of the source and the recipient country where the taxpayer is resident) and is undesirable because it reduces profits and discourages economic subjects from engaging in activities in other countries (Široký, 2018).

Treaties on the limitation of double taxation are bilateral treaties which are usually concluded between countries based on the OECD model treaty (Miller, Mulligan \& Oats, 2017, chapter 7). This model treaty has got a standardised structure. The opening four articles concern the designation of the residence of taxpayers, while the other articles concern themselves with the area of direct entrepreneurial activities in a treaty state, including an article concerning the taxation of income from real estate. Other articles pertain to dividends, interest and licence fees. The treaties then focus on the taxation of the income of natural persons, including income from employment, self-employment, profit shares, the earnings of artists and sportspeople, pensions, public services and other income. Each of the treaties contain article which resolves the issue of double taxation or designate the method which should be applied when excluding double taxation. These include exemption methods and credit methods.

According to the Czech Ministry of Finance website (2021), as of 26 July 2021 the Czech Republic had concluded a total of 92 treaties on the limitation of double taxation. The gradual preparation of these treaties, including any eventual changes to them, is undertaken by the International Taxation Department. Once the text of the treaty has been negotiated with the international partners, it must be ratified by the parliaments of both countries. In the Czech Republic, a treaty must be, after being ratified by parliament, signed by the President of the Republic. The treaties are published in the Collection of Laws and since 1 January 2000 in the Collection of International Treaties. Amongst the oldest treaties is also the treaty on double taxation avoidance with the Netherlands, published as Decree No.138/1994 Coll. of the 
Minister of Foreign Affairs of 22 November 1974 on the Convention between the Kingdom of the Netherlands and the Czechoslovak Socialist Republic for the avoidance of double taxation and the prevention of fiscal evasion with respect to taxes on income and capital. Since this treaty was concluded 47 years ago, many changes have occurred in national law and socioeconomic conditions, and the approaches to international taxation have evolved (Miller, Mulligan \& Oats, 2017). Despite the completely different situation of the waterborne transport today, the provisions of the treaty became applied to Czech boatmen working in the Netherlands. This has got a fatal impact on a number of Czech citizens who, after the socioeconomic changes in Czechoslovakia in 1989, found employment as boatmen in international river and canal transport with Dutch companies, when this profession was restricted in the Czech Republic following the privatisation of a historically important shipping company.

Article 16, paragraph 3 of the Czechoslovakia - the Netherlands treaty states that: "Any remuneration which an individual, whose place of residence is located in one of the two states, receives as a result of any employment undertaken on board a ship used in international transport or on board a boat used in inland waterborne transport will be subject to taxation only in that state regardless of the previous provisions of this article." The ambiguity of the wording of this article has further been enhanced by the fact that, unlike treaties with other countries, the treaty with the Netherlands does not contain a definition of international ship transport, but merely refers to domestic legal regulations in article 3 , paragraph 2 .

According to Miller, Mulligan \& Oats (2017, p. 213), OECD model treaty tackles "international ship, boat and aircraft crew in paragraph 3 of Article 15, which deals specifically with remuneration of crews of ships or aircraft operated in international traffic, or boats engaged in inland waterways transport. The rule provides for tax in the contracting state in which the place of effective management of the enterprise concerned is located, consistent with Article 8. Also consistent with Article 8, however, states can agree to confer taxing rights on the state of the enterprise operating the ships, boats or aircraft, on the assumption that domestic law facilitates this."

It is therefore clear that the 1974 double taxation treaty with the Netherlands differs from the OECD model treaty in that it mentions the country of tax residence of the employees instead of the country of taxation of the listed professions.

A further ambiguity in the wording of article 16, paragraph 3 of the treaty with the Netherlands concerns the mention of "employment undertaken on board a ship used in international transport or on board a boat used in inland waterborne 
transport". According to Adamec (2008), waterborne transport is one of several types of transport which is divided up according to the area in which the transport route is located. A further criterion for the division of transport, including water transport, involves the territorial division of transportation or requirements, namely into local, national and international. This clearly shows that waterborne transport is a type of transport which is secured by sailing along watercourses, artificial and natural lakes, seas, oceans and artificial channels and canals and which may take place above or below the surface of the water. Waterborne (ship) transport can be divided into maritime and inland transport (inland transport is understood to mean river and lake transport), while some vessels may sail from rivers into the sea. It is apparent from this definition that international ship transport consists of interstate inland transport as well as maritime transport. It is precisely within the framework of such international inland transport that the aforementioned Czech boatmen carry out their employment on board Dutch ships. The term "a boat used in inland waterborne transport" does not fall under international transport and it therefore only marginally concerns the boatmen.

Before November 1989, i.e. in the period of the centrally planned economy, ČSPLO company (see chapter 2 lower) also transported freight on rivers and canals abroad using its own ships and personnel, but the wages were paid out by this company and taxed in Czechoslovakia, regardless of which countries the ships were sailing in. Article 16, paragraph 3 of the treaty with the Netherlands was therefore completely irrelevant up to 1989, just like comparable articles contained in treaties concluded with other states. The conditions for the application of the treaties regarding international transport changed as a result of the following economic transformation in the Czech Republic and with the departure of hundreds of Czech boatmen abroad, where they found work with employers whose ships sailed along inland watercourses.

\section{The development of Czech waterborne transport companies}

Czech rivers were used as transport routes in historical times. Later, the ship transport industry began strong development on the Elbe River, providing not only domestic ship transport, but also transport on an international scale (Švarc, Vanner, Zídek, 1984).

The current Československá plavba labská, a.s. (the Czechoslovak Elbe Shipping joint stock company, hereafter simply referred to as ČSPL, a.s.) company with its registered office in Děčín, was established on 13. 6. 1922 as the Československá plavební akciová společnost Labská, Praha (Czechoslovak Elbe Shipping Joint Stock Company, Prague). It was founded by the state of 
that time and by banks. The company undertook all activities which were associated not only with the transportation of goods and people, but also with the construction and repair of ships. Ship transport was not interrupted during the Second World War though the company was germanised by force. The majority of the bridges were destroyed, and many ships were sunk on the German stretch of the Elbe River towards the end of the war as a result of the shift in the front. The company was left with a total of 267 vessels after the occupation. On 1. 1. 1949 it was subsequently nationalised and continued its activities as a waterborne transport company, Československá plavba labská národní podnik (the Czechoslovak Elbe Shipping National Enterprise).

A company merger took place on 1.7. 1952 which led to the establishment of the Československá plavba labsko-oderská, národní podnik (Czechoslovak Elbe-Oder Shipping National Enterprise, hereafter simply referred to as ČSPLO). ČSPLO gradually expanded its activities and in 1989 it had almost 4000 employees and was operating 700 vessels. The socioeconomic change in 1989 was followed by a period of privatisation which culminated on 5. 5. 1992 when ČSPL, a.s. was established. However, the company went into decline in the following decade, culminating in the bankruptcy and sell-off of the individual functioning parts of ČSPL, a.s. The company's main activity, i.e. the operation of fluvial freight transport, predominantly abroad, was purchased by ARGO Internationale Spedition, s.r.o., part of the AFG holding group, and registered as ČSPL, a.s. on 21. 10. 2002. ČSPL, a.s. currently has a total of 205 employees and 73 vessels (Argo Group, 2017). This means that only a fraction of the vessels has been preserved in the Czech Republic and that the number of jobs in this profession has been significantly reduced.

After the bankruptcy of the original ČSPLO waterborne transport company, hundreds of professionally skilled boatmen, who continue to be residents of the Czech Republic, found new jobs in other EU countries which are connected by a dense European network of rivers and canals. This especially involves the Kingdom of the Netherlands, Germany, Luxembourg, Belgium and Denmark.

\section{The method of taxing income from abroad in the Czech Republic}

According to the provisions of section 2 of Income Tax Act No. 586/1992 Coll. (hereafter simply referred to as the Income Tax Act), taxpayers who have their place of residence within the Czech Republic or who usually dwell there are obliged to pay tax on any earnings from the Czech Republic and abroad.

It does not matter if the income from abroad has come from a country with which an international treaty on the prevention of double taxation (hereafter simply referred to as a treaty) has been concluded. If no such treaty exists, the 
tax must be paid in full in the Czech Republic, even if the earnings in question have already been taxed abroad. On the other hand, if a treaty has been concluded, this usually leads to the so-called prevention of double taxation according to the provisions of section $38 \mathrm{f}$ of the Income Tax Act. However, the prerequisite for this is that the taxpayer must substantiate the tax which has been paid abroad to the Czech tax administration by means of confirmation from the foreign tax administrator. Generally, any earnings from employment undertaken in a state with which the Czech Republic has concluded a treaty, which are paid to any residents of the Czech Republic by an employer which is a resident of the state in which any such activities have been undertaken are exempt from taxation, provided the aforementioned earnings have been taxed in the state where they were paid out. Simply put, it is possible to state that most treaties include provisions whereby any wages received during employment are primarily taxed in the country where the employment is undertaken. It is, however, necessary to respect the wording of each specific bilateral treaty.

An analysis of the valid bilateral treaties has ascertained that in the case of the treaties with the Kingdom of the Netherlands, Norway and the United Arab Emirates any income arising from employment undertaken on board a ship or an aircraft used in international transport is not taxed in the country of the employer's registered office, but in the country of residence of the employee, in this case in the Czech Republic. Czech citizens employed in the aforementioned professions in these countries are obliged to submit a tax return after the end of the calendar year and to do so within the legal deadline, usually by $1^{\text {st }}$ April. None of the tax exemption methods stated in section $38 \mathrm{f}$ of the Income Tax Act are used, because taxpayers are obliged to tax the annual gross wage which they have received abroad in accordance with the Czech Income Tax Act.

The tax base for income from employment is the gross wage increased by $34 \%$, which has been the method used in the Czech Republic since 2008 until 2020. The stated increase represents the amount of the social and health insurance contributions paid by the employer in the Czech Republic for each employee over and above the framework of the gross wage. This tax base, which is wider than that used in other countries, is called the super-gross wage. This is only taxed at a rate of $15 \%$ up to four times the average wage, which corresponds to approximately $20 \%$ of the gross wage. In reality, however, both insurance contributions are paid for the boatmen by their foreign employers at completely different percentages of the gross wage. Furthermore, as taxpayers who do not keep accounts, they are obliged to convert their earnings in a foreign currency using a uniform exchange rate which the Financial Administration of the Czech Republic publishes every year in its methodological instruction. It must be stated in this regard that the exchange rate in relation to the euro is significantly 
overvalued, whereby this culminated in the period from 2013 to 2017 at a level of more than $27 \mathrm{CZK} / \mathrm{EUR}$ (see table 2), when the Czech National Bank (CNB - Czech Republic's central bank) realised its so-called foreign exchange intervention for the purpose of lowering the inflation rate and keeping it within the optimum inflation target $(1 \%-3 \%)$ which had been set since 1999 .

Given the fact that Norway does not have the conditions for fluvial transport which exist in Western Europe and that there are almost no rivers in the UAE, the treaty with the Kingdom of the Netherlands would appear to be the most serious of these three treaties. This fundamental exception in the taxation of income from employment was not generally known to the local tax authorities, let alone to the Czech boatmen, until quite recently. After the unsuccessful privatisation of ČSPLO, many boatmen, who had been made redundant, found new jobs in the Netherlands. The boatmen concluded employment contracts there and their Dutch employers deducted income tax and social insurance contributions, part of which included pension insurance, and national health insurance contributions in the country of their registered office until the year 2016. According to the valid treaty, the employers should not have deducted any tax on earnings in the Netherlands and the boatmen should have paid this tax to the tax authorities in the Czech Republic. This was agreed by the tax authorities and financial offices of both countries.

\section{The change in the approach of the tax administrators to the taxation of boatmen employed in the Netherlands}

In September 2016, the General Financial Directorate (hereafter simply referred to as the GFD), which is the central body of the Financial Administration of the Czech Republic, received a list of the names of several hundred Czech boatmen employed in the Netherlands as part of the automatic exchange of information between the financial administrations of the countries of the EU. After a meeting with the Ministry of Finance of the Czech Republic, individual tax offices began requiring the boatmen to submit tax returns retroactively from 2013 and to pay any outstanding taxes. Moreover, the tax administrators from the tax offices which had sent the demands to the boatmen provided incorrect answers to the boatmen's queries with regard to the place of the payment of their taxes in the same period.

As a result of the given situation, the contacted boatmen established the Spolek lodníků - zájmové sdružení oborové skupiny zaměstnanců na ochranu svých hospodářských a sociálních zájmů, z. s. Děčín (Boatmen's Association - an association of a unionised group of employees for the protection of their economic and social rights) and contacted politicians, lawyers and tax experts 
with a request for assistance (hereafter simply referred to as the associates). The first meeting of the association's representatives and its associates took place at the Ministry of Finance of the Czech Republic in September 2016. Due to the anticipated high financial impacts, they advanced a proposal for the submission of a request to waive the tax on the grounds of discrepancies arising from the tax laws (the provisions of section 260 of the Tax Code). The signature of the Minister of Finance on a positive decision could have rendered the situation of the Czech boatmen employed in the Netherlands less dramatic, i.e. without the substantial social impacts which had begun to appear. However, the Ministry of Finance had already reached the decision that it would not comply with this request.

As a result, the issue of the boatmen was resolved at the level of the Budget Sub-Committee of the Chamber of Deputies of the Parliament of the Czech Republic due to its serious nature and the concomitant social impacts. The GFD admitted the completely fundamental lack of knowledge amongst its tax administrators in the Information on the option of applying for the waiver of income tax penalties from employment performed on board ships and boats operated in inland and international transport in the Netherlands which it published in July 2017 at the request of the Budget Sub-Committee. The moderation of the conditions for the waiver of the tax penalties by the tax administrator in comparison with the valid conditions for all other tax subjects was requested at this level by the boatmen's association and its associates. In reality, however, the Czech Financial Administration did not implement any significant moderation of the stated conditions. This became clear from the answers given by individual boatmen who had been questioned on this by the representatives of the Association.

The materials of the Ministry of Finance of the Czech Republic for the meeting of the members of the Budget Sub-Committee on 12.7.2017 clearly shows that the Financial Administration had investigated 408 boatmen in relation to the individual years. The enumeration of the additionally levied taxes for the period from 2013 to 2016, including the sanctions, as of 7.7.2017 is contained in the following Table 1. 
Table 1: The taxation of Czech boatmen working on board ships in the Netherlands for the taxation period from 2013 to 2016

\begin{tabular}{|c|c|c|c|c|c|}
\hline & 2013 & 2014 & 2015 & 2016 & Total \\
\hline \multicolumn{6}{|l|}{ Tax return } \\
\hline count & 376 & 368 & 167 & 113 & 1024 \\
\hline CZK amount & 20481698 & 21034298 & 15328435 & 9966854 & 66811285 \\
\hline \multicolumn{6}{|c|}{ Fees for late tax return } \\
\hline count & 197 & 163 & 115 & 2 & 477 \\
\hline CZK amount & 892473 & 887441 & 162850 & 9245 & 1952009 \\
\hline \multicolumn{6}{|c|}{ Interest on late payments } \\
\hline count & 141 & 138 & 122 & 9 & 410 \\
\hline CZK amount & 5631410 & 3639930 & 1333531 & 16093 & 10620964 \\
\hline \multicolumn{6}{|l|}{ Total } \\
\hline CZK amount & 27005581 & 25561669 & 16824816 & 9992192 & 79384258 \\
\hline
\end{tabular}

Source: Ministry of Finance, 2017

The amount of just under 80 million CZK is negligible from the point of view of the public budget, but the individual tax levy has often had a fatal impact on the standard of living of the families of the individual boatmen, as is apparent from the following text.

According to the information from the boatmen's association, boatmen in the Netherlands usually receive the minimum wage or a wage slightly above the minimum. This is changed twice a year, on $1^{\text {st } J a n u a r y ~ a n d ~} 1^{\text {st }} \mathrm{July}$. The amounts for employees who are under 23 years of age are set out in Table 2 below. The term "resident" is not defined in the Dutch Income Tax Act and the fact as to whether an individual is considered to be a resident or non-resident is decided on a case-by-case basis. The tax rate on the income of natural persons differs for various types of income which are divided into three categories. The tax rate for the first category (this especially involves the taxation of wages) is progressive with four tax bands. In addition to income tax, since 2016 the tax administrator also collects social insurance contributions, as well as national health insurance contributions, in the first two bands (Tax Consultants International BV, 2019).

Table 2: The development of the minimum gross wage in the Netherlands and the calculation of the tax on income from employment in the Netherlands and in the Czech Republic in the period between 2013 and 2018 
Czech boatmen employed in the Netherlands: Unusual income taxation ...

\begin{tabular}{|c|c|c|c|c|c|c|c|c|c|}
\hline $\begin{array}{l}\text { Date of } \\
\text { minimum } \\
\text { gross wage } \\
\text { change in } \\
\text { NL }\end{array}$ & \begin{tabular}{|c|} 
Gross \\
monthly \\
minimum \\
wage in NL \\
in $€$ \\
\end{tabular} & $\begin{array}{c}\text { Tax rate in } \\
\mathrm{NL} \text { in } 1 . \\
\text { tax } \\
\text { bracket in } \\
\%\end{array}$ & \begin{tabular}{|l|} 
Advance \\
on income \\
$\operatorname{tax}$ in NL \\
in $€ /$ mont \\
$h$
\end{tabular} & \begin{tabular}{|l|} 
Advance on \\
income tax \\
in NL in \\
CZK/month
\end{tabular} & \begin{tabular}{|c|}
$\begin{array}{c}\text { Exchange } \\
\text { rate } \\
\text { according } \\
\text { to Czech } \\
\text { tax office } \\
\text { in CZK/€ }\end{array}$ \\
\end{tabular} & \begin{tabular}{|l} 
Gross \\
monthly \\
minimum \\
wage in NL \\
in CZK
\end{tabular} & \begin{tabular}{|l|} 
Czech tax \\
base (gross \\
wage $x$ \\
$1,34)$ in \\
CZK
\end{tabular} & $\begin{array}{l}\text { Advance on } \\
\text { income tax } \\
\text { in Czech } \\
\text { rep. in } \\
\text { CZK/month }\end{array}$ & $\begin{array}{l}\text { Share of } \\
\text { tax } \\
\text { advance } \\
\text { in Czech } \\
\text { rep. and } \\
\text { NL }\end{array}$ \\
\hline 01.01 .2013 & 1469,40 & 5,85 & 85,96 & 2238 & 26,03 & 38248 & 51253 & 7688 & 3,4 \\
\hline 01.07 .2013 & 1477,80 & 5,85 & 86,45 & 2250 & 26,03 & 38467 & 51546 & 7732 & 3,4 \\
\hline 01.01 .2014 & 1485,60 & 5,10 & 75,77 & 2087 & 27,55 & 40928 & 54844 & 8227 & 3,9 \\
\hline 01.07 .2014 & 1495,20 & 5,10 & 76,26 & 2101 & 27,55 & 41193 & 55198 & 8280 & 3,9 \\
\hline 01.01 .2015 & 1501,80 & 8,35 & 125,40 & 3420 & 27,27 & 40954 & 54878 & 8232 & 2,4 \\
\hline 01.07 .2015 & 1507,80 & 8,35 & 125,90 & 3433 & 27,27 & 41118 & 55098 & 8265 & 2,4 \\
\hline 01.01 .2016 & 1524,60 & 8,90 & 135,69 & 3669 & 27,04 & 41225 & 55242 & 8286 & 2,3 \\
\hline 01.07 .2016 & 1537,20 & 8,90 & 136,81 & 3699 & 27,04 & 41566 & 55698 & 8355 & 2,3 \\
\hline 01.01 .2017 & 1551,60 & 8,90 & 138,09 & 3630 & 26,29 & 40792 & 54661 & 8199 & 2,3 \\
\hline 01.07 .2017 & 1565,40 & 8,90 & 139,32 & 3663 & 26,29 & 41154 & 55147 & 8272 & 2,3 \\
\hline 01.01 .2018 & 1578,00 & 9,00 & 142,02 & 3647 & 25,68 & 40523 & 54301 & 8145 & 2,2 \\
\hline 01.07 .2018 & 1594,20 & 9,00 & 143,48 & 3685 & 25,68 & 40939 & 54858 & 8229 & 2,2 \\
\hline
\end{tabular}

Source: MINIMUMLOON NL, KURZY.CZ.

Table 2 clearly shows that the minimum wage in the Netherlands has grown regularly, but that it has always been taxed within the first tax band, where the rates and amounts of tax also rose. The amount of tax has also been calculated in $\mathrm{CZK}$ according to the methodology for calculating tax on income from employment in the Czech Republic. No tax relief has been applied in either case on grounds of comparability. It is clear from the last column of Table 1 that the amount of tax in the Czech Republic is several times higher when compared with the Netherlands, while the highest values were achieved in 2014 at almost four times the amount. This is given by the high degree of progressiveness in taxation in the Netherlands.

If a boatman had only the minimum (gross) wage in the Netherlands, this amounted to a total tax bill without tax relief of $390,382 \mathrm{CZK}$ in the period from 2013 to 2016 and 587,452 CZK in the period from 2013 to 2018 (and in some cases, even more was required). The boatmen did not have such significant funds available to pay their tax obligations in the Czech Republic. They were therefore able to request the deferment or instalment-based payment of the taxes according to the Tax Code. After the payment of the outstanding taxes, the tax administrator issued a payment notice for default interest at an amount of several tens of thousands of CZK. The tax administrator waived the interest based on a tax remission application, which is subject to a fee, either rarely or not at all, not only because of the original conditions, but also the new conditions for compliance with the application were overly strict. At the same time, payment notices were also issued with penalties for the late submission of tax returns, especially for the tax period from 2013 to 2015. This once again involved thousands of CZK. The Tax Code does not allow for any such penalties to be waived and as such this amounted in practice to a surcharge on 
the assessed tax obligation alongside the unremitted default interest. After the media coverage of the matter and requests from their Czech employees (the boatmen), the Dutch employers ceased deducting instalments for tax on income from employment from 2017 onwards. By contrast, the Financial Administration of the Czech Republic began to require the boatmen to pay regular monthly instalments on tax from employment according to the Czech regulations from 2017. However, in reality this merely involved the accumulation of further tax arrears.

Many boatmen and their families still have ongoing existential problems. Even though it is possible to request a tax refund in the Netherlands up to five years retroactively, this usually does not cover the outstanding tax and sanctions in the Czech Republic. Moreover, any such application for a tax refund from the Netherlands is an administratively, financially and time-consuming matter, for which the boatmen hire experts in Dutch tax law and translators. The Tax Administration in the Netherlands has up to one year to refund the tax by law. Boatmen often do not receive any tax refund from the Dutch tax administration, because their employer did not pay any income tax for them as a result of the applied tax relief and, if some tax relief has been applied, they are also required to return any so-called negative tax. As such this involves further expenditure, this time to the Dutch administrative authorities. Four years ago, Czech boatmen have been required by the Financial Administration in the Netherlands to submit tax returns there, even though they have their tax domicile in the Czech Republic. It is therefore clear that the tax authorities in the Czech Republic and the Netherlands have not effectively coordinated their tax collection activities and that transaction costs are rising which are borne by the weakest link in the entire chain, i.e. the Czech boatmen.

The entire fundamental problem lies in the fact that the Financial Administration in the Netherlands is not able to separate the tax and insurance contributions which are paid in the first two lowest tax bands. As a result, boatmen are often also refunded their social insurance contributions based on the applications, so they will either not have any pension insurance in the future, which is a fundamental problem, or the Dutch tax administration subsequently requires them to repay these insurance contributions. However, social security benefits in the Netherlands not only include old age pensions, but also widows' benefits, exceptional healthcare expenses and children's allowances. Some boatmen, fearing that their social insurance contributions from the Netherlands could also need to be refunded, do not even request a tax refund.

This shows that, in addition to the problem of tax which can be resolved using the principle of preventing any undesirable double taxation (albeit with high transaction costs), the problem of social insurance, which currently constitutes a significant percentage of work income, has not been effectively resolved 
between the Czech Republic and the Netherlands. Moreover, it is possible that part or even all the social pension insurance contributions are not effectively separated from the income tax and that it will be necessary to carry out further investigations or research in this regard so that it is clear which part of the deductions pertains to general income tax and which part pertains to social insurance contributions, especially in relation to pension entitlements or child allowances. Representatives of the boatmen and the Ministry of Labour and Social Affairs were contacted regarding this in May 2019. To date, however, this has not met with any tangible results.

\section{A partial solution to the issue of the boatmen}

In response to the aforementioned situation, a parliamentary proposal was submitted at the beginning of 2018 as an amendment to the Income Tax Act (the Chamber of Deputies, 2018) with the objective of moderating the negative impacts on the boatmen employed in the Netherlands. A proposal was made to cancel the increase of earnings from employment realised abroad by the amount of the compulsory insurance contributions which apply to earnings from employment in this country (the so-called super-gross wage). Boatmen's employers abroad pay these amounts of insurance contributions at a level which is completely different to that which is applied in the Czech Republic. Moreover, it was proposed that the tax base in the Czech Republic should be reduced by any insurance contributions which their employers abroad had deducted from their gross wage. This was proposed to come into effect as of 1 January 2018.

The government of the Czech Republic issued a negative statement about this proposal in which it stated that the proposed change did not affect the essence of the problem set out in the statement of the reasons. According to the government's statement, the proposal merely concerns the elimination of the so-called super-gross wage, but only in the case of earnings from employment abroad, and the question of the ability to separate the compulsory insurance contributions from the income tax base on earnings from employment abroad, albeit only in the situation where the taxpayer receives earnings from employment in a state with which the Czech Republic has concluded a treaty on the elimination of double taxation and where these earnings are subject to taxation in the state where the employee has his or her place of residence. In the government's opinion, the elimination of the so-called super-gross wage only in the case of earnings from employment undertaken abroad would have constituted unjustified discrimination in relation to all other tax residents. 
At the same time, the government pointed out that the elimination of the socalled super-gross wage from the calculation of the tax base from the entire Income Tax Act (i.e. both in relation to earnings arising from employment realised abroad and to those earnings acquired within the Czech Republic) constituted part of the draft law which had been submitted by the Ministry of Finance and which would change some other laws in the area of tax from 2019. In its statement, the government believed the section of the proposed amendment pertaining to the elimination of the so-called super-gross wage was groundless, while also stating that there was currently no reason to do so purely in relation to income received from employment undertaken abroad.

The parliamentary proposal was modified by means of a proposed amendment in the Budget Sub-Committee on 6 June 2018 so that the income tax base from earnings abroad was set as the sum of the gross wage and the insurance contributions were deducted by the employer abroad. For example, this amounts to $18 \%$ of the gross wage in the Kingdom of the Netherlands (the Netherlands, 2017). The effectiveness of the amendment was moved to 1 January 2019 in order to limit any retroactivity. The Chamber of Deputies discussed the draft amendment to the Income Tax Act at its session on 12 September 2018 and then sent the amendment to the Senate. The Upper Chamber of the Parliament of the Czech Republic rejected the proposal, but the Chamber of Deputies overrode the Senate's veto.

The following Table 3 compares the amount of the tax paid in the Czech Republic by boatmen employed in the Netherlands prior to the amendment to the Income Tax Act and after the amendment from 1 January 2019 with the application of a single tax credit per taxpayer at the amount of 24,840 CZK/year. 
Czech boatmen employed in the Netherlands: Unusual income taxation ...

Table 3: The taxation of the income of employees with various amounts of income from abroad

\begin{tabular}{|l|r|r|r|r|}
\hline Gross monthly wage in NL in $€$ & $\mathbf{1 5 5 0}$ & $\mathbf{2 ~ 0 0 0}$ & $\mathbf{2 5 0 0}$ & $\mathbf{3 0 0 0}$ \\
\hline Gross yearly wage in NL in $€$ & 18600 & 24000 & 30000 & 36000 \\
\hline Gross yearly wage converted to CZK $(25,68 \mathrm{CZK} €)$ & 477648 & 616320 & 770400 & 924480 \\
\hline Tax base before new tax code (gross wage +34\%) & 640048 & 825869 & 1032336 & 1238803 \\
\hline Income tax with rate 15\% before new tax code & $\mathbf{7 1 ~ 1 6 7}$ & $\mathbf{9 9 0 4 0}$ & $\mathbf{1 3 0 0 1 0}$ & $\mathbf{1 6 0 9 8 0}$ \\
\hline Tax base before new tax code (gross wage +18\%) & 563625 & 727258 & 909072 & 1090886 \\
\hline Income tax with tax rate 15\% after new tax code & $\mathbf{5 9 7 0 4}$ & $\mathbf{8 4 ~ 2 4 9}$ & $\mathbf{1 1 1 ~ 5 2 1}$ & $\mathbf{1 3 8 7 9 3}$ \\
\hline Difference in income tax before and after the new tax code & $\mathbf{- 1 1 ~ 4 6 4}$ & $\mathbf{- 1 4 7 9 2}$ & $\mathbf{- 1 8 4 9 0}$ & $\mathbf{- 2 2} \mathbf{1 8 8}$ \\
\hline
\end{tabular}

Source: author's calculations

The tax savings grow with any increased earnings, albeit not that significantly. It can be stated that the legal regulation will not overly help boatmen employed in the Netherlands and their families in their current social situation.

The super gross wage as the basis for employment income tax was abolished in the Czech Republic at the end of 2020 and replaced by the gross wage with a $15 \%$ tax rate. This was a political decision with an impact on the wages of employees in the Czech Republic in the 2021 election year. From this year onwards, Czech boatmen employed in the Netherlands also pay lower advance tax payments to the Tax Administration in the Czech Republic. Even so, the taxation of their wages in the Netherlands would be lower.

\section{Results}

From September 2016 to September 7, 2017, the Financial Administration charged 408 boatmen employed in the Netherlands taxes at the amount of just under 80 million CZK, of which almost $16 \%$ was tax penalties. From the point of view of the public budget of the Czech Republic, this involves a completely negligible amount of income from past fiscal periods, but it is fatal for the boatmen and their families. The threat of the distrainment of property by the tax administrator not only applies in the case of a failure to pay any taxes, but also during the permitted payment of taxes "in instalments". The boatmen and their families are therefore living under a significant amount of existential insecurity.

The reasons for this critical situation are:

- the low earnings of the boatmen in the Netherlands which do not significantly exceed the minimum wage,

- the different levels of taxation in the Netherlands (highly progressive taxation) and in the Czech Republic (taxation is proportional for the majority of employees with a rate of $15 \%$, albeit from a wider tax base); 
- according to section 6, subsection 13 of the Income Tax Act, any earnings from employment abroad converted using the uniform exchange rate were also increased by insurance contributions of $34 \%$ up to the end of 2018, as if the earnings had been paid in the Czech Republic; however, the insurance contributions in the Netherlands are paid at a level of $18 \%$ of the gross wage and this has not been used for the calculation of the tax base in the Czech Republic until 2019,

- the uniform euro (EUR) - Czech koruna (CZK) exchange rate is significantly unfavourable for the conversion of earnings from employment.

The options for a solution to this burdensome situation, in which a significantly large group of Czech citizens has found itself:

- $\quad$ in the initial phase of the solution, it was possible to waive taxes in accordance with section 260 of the Tax Code on the grounds of discrepancies arising from the tax laws; however, the Ministry of Finance did not find this circumstance to be legal in 2016,

- waiving the default interest - the boatmen did not meet the conditions for a waiver according to the GFA's methodological instruction no. D21. As such, new waiver conditions, which were slightly more favourable than the previous conditions, were established in the middle of 2017 on the basis of a meeting of the Budget Sub-Committee,

- a change in the tax domicile to the Netherlands; the condition of the boatmen being absent from the Czech Republic for more than 183 days has been met,

- $\quad$ the amendment of article 16, paragraph 3 of the treaty - on 30.8.2017, the members of the Budget Sub-Committee approved a resolution in which they requested the Minister of Finance to have the Ministry of Finance draw up a new draft of the treaty on the elimination of double taxation between the Czech Republic and the Kingdom of the Netherlands which would correspond to the usual treaties of this type applied between EU states, for example between the Czech Republic and Germany. At the same time, they requested the government to call a meeting to discuss a change in the treaty with the Kingdom of the Netherlands. However, this is a long-term solution which will take at least two to three years,

- $\quad$ an amendment to section 6, subsection 3 of the Income Tax Act, which omits the increase of earnings from employment by the amount of the insurance contributions paid by the employer for the employee and enables employees who have to tax their own earnings from employment abroad in the Czech Republic to reduce these earnings by a legally designated amount, for example by the amount of the 
insurance contributions paid from their gross wage abroad, any costs associated with travelling to their work abroad and so on. This alternative was not only introduced for boatmen employed in the Netherlands, but for all Czech employees from 2021 onwards,

- Slovakia's solution - this neighbouring country was part of Czechoslovakia until the end of 1992 and is subject to the same treaty as the Czech Republic. Slovakia, however, in its Act No. 595/2003 Coll., on Income Tax, in the provisions of section 45(3)(c), exempted its citizens employed as boatmen in the Netherlands: "The income exclusion method shall be applied if the taxpayer with unlimited tax liability receives income from dependent activities from sources abroad from a state with which the Slovak Republic has concluded a double taxation treaty and such income has been demonstrably taxed abroad, if this procedure is more advantageous for the taxpayer." This change in Slovakia was inspired by Slovak approach to application of general anti-avoidance rules (GAAR), as they were analysed by Koroncziová and Kacaljak (2018).

\section{The discussion and conclusions}

It is apparent that the taxation of income can be a very thorny issue, especially in the case of common people who do not have the funds for advisers to help them suitably deal with their tax obligations and for whom the disproportion during the assessment and collection of tax means the risk of fundamental existential difficulties. Naturally, it is possible to find technically correct solutions when one undertakes a detailed analysis of the problem, as we have done here, but any such analysis can only be undertaken at an expert level and ex post. It is therefore clear that it has not been in the power of the affected individuals to resolve this manner by themselves or to anticipate how the given matter would turn out when performing their profession.

The problem has arisen in the presented case due to the fact that working on board a ship falls under a specific taxation regimen on the basis of a long since concluded treaty, that the conversion of earnings from abroad into the Czech currency leads to a significantly different category of earnings (that which is a low or even a minimum income in the Netherlands becomes a higher income after being converted into Czech koruna) and that there is a specific method of taxing income in the Czech Republic, whereby the income is supplemented with a higher rate of health and social insurance contributions. As a result, their earnings are converted using the exchange rate and then increased by one third, although this has only been by $18 \%$ since 2019 . This is then the amount on which they must pay Czech income tax. The result is at least double the tax 
obligation in the Czech Republic when compared with that in the Netherlands. They therefore must pay the difference from their personal earnings.

The taxation of earnings primarily in the "country of origin" eliminates both the exchange rate risk and the problem with the application of Czech tax regulations on international earnings and the influence of a uniquely Czech factor, i.e. the super-gross wage, on the taxation of income from employment. As such, it is optimal, if this practice results from the application of the treaties and legal regulations pertaining to income tax. Unfortunately, however, the provisions of the international treaty with the Netherlands prevent this principle from being applied.

It is also somewhat absurd that the described state of affairs has occurred between two member states of the European Union, where significant efforts are made to not overly complicate the free movement of individuals on the one hand, but where a bilaterally agreed tax regimen has led to such surprising results on the other hand.

If there is no willingness to amend the given international treaty with the Netherlands so that the income of employees on board ships or planes is taxed according to the local regulations (which is the best solution), then it is clear from the point of view of tax fairness that the significantly higher taxation of earnings according to Czech laws is overly severe for the boatmen, especially when compared with other professions, for example in transport. It is clear that the Czech authorities' argument has been based on a comparison with other Czech taxpayers in accordance with the fact that the taxation of all residents must be subject to the same principles. The problem is, however that this does not involve the same tax base. After all, the Dutch tax base i.e. the gross wage from the point of view of the logic of the labour market, corresponds to the Czech gross wage and not the super-gross wage which, despite political efforts, has not become the subject of wage bargaining or even advertisements in the labour market. As such, it should be appropriate at the very least to apply the amount of the gross wage when taxing the boatmen's tax base and not the supergross wage.

This would at least compensate for the specific Czech regimen which applies to the taxation of work income, which moreover did not even exist at the time when the treaty was concluded (1974) and as such the treaty's authors could not have thought through the impact of the agreed exceptions in this regard.

It is also impossible to ignore the social and psychological impacts of the entire process, whereby we have substantiated that the entire matter has been ongoing for a number of years and that it is subject to the political cycle and the possibility of discussing the given proposals in Parliament, which admittedly 
does not change the material logic of the problem, but the failure to discuss or bind the solution to any further legislative changes means that a possible solution is further complicated and even blocked.

The case of the boatmen and the Netherlands thus proves the inflexibility of Czech tax policy when resolving specific problems pertaining to groups of citizens with regard to their work income. It is possible to find and recommend solutions which are acceptable from the point of view of their tax and social fairness at an expert level, but the legislative application of these solutions is extremely difficult.

It is somewhat astonishing that the Ministry of Finance has not come up with any of the proposed solutions set out in Chapter 5. It is convinced that it collects taxes in accordance with the law and refuses to admit any misconduct on the part of the tax administrators who have provided the boatmen with incorrect information in the past, as has been substantiated by a number of documents. It is not possible, however, to reproach the tax administrators for this, because, on the contrary, this substantiates the fact that this involves a completely unique matter, of which they may well not have been aware. The Ministry does not even find it strange that this completely unique exception increases the direct and indirect administrative costs for the collection and administration of taxes. Instead of concerning themselves with serious tax evasion, the tax administrators are encumbered by this agenda which has been concentrated within the jurisdiction of the Tax Office for the Ústí Region.

The principles of tax theory speak in favour of the taxation of earnings in the period when they are acquired and that this should occur once at a rate pertaining to the tax base which has been designated by fiscal rules which are foreseeable for the subject of the tax and are accompanied by reasonable transaction costs. If the described problem is viewed from the point of view of the theory of elastic money which dominates current monetary policy, this does not mean that any outstanding receivables or tax should not be recovered, but that the given tax yield is not realistically missing within the (Czech or European) economy, especially if it has been compensated for by the relaxed monetary policy which has been apparent in recent years. The boatmen taxed their earnings in the Netherlands in good faith, they were left with greater earnings from the productive factor of work (not speculative or passive earnings), and they were therefore able to consume more in the Czech Republic. This meant that more indirect tax, especially VAT, was collected in this country. If they are additionally subjected to very high-income tax on earnings from employment in the Czech Republic, they will be left with less money for consumption. It is theoretically possible that the tax yield for the public purse in such a case could even be lower because the breach of the basic principles of 
the effective collection of taxes negatively influences the behaviour of the economic subjects participating in the transactions in question.

It can be inferred that the approach of the Ministry of Finance in this case has been dominated to date by a mechanistic philosophy of "assess and collect income tax not paid in the Czech Republic" regardless of the historical and factual context of the entire case. This approach is logical and correct in standard cases of income tax arrears, but in this case, it has been mechanically applied to a situation where the fiscal yield from earnings in economic practice has been acquired according to the rules of a different EU member state. The proposed solutions mentioned in Chapter 5 will have a minimum fiscal impact on the Czech Republic and moreover they pertain to entitlements from previous fiscal periods. It can therefore be generally recommended that, if a decision of the state administration so allows, the boatmen should not be required to make any additional fiscal payments and possibly (preferably on a one-off basis) any tax yield paid in the past should be transferred from the Netherlands to the Czech Republic, provided the tax regulations of both countries and the EU so allow. The international treaty with the Netherlands should then be modified for the future regarding boatmen or employees of airlines so that the majority rule of taxation in the country where the employer has its registered office should also apply to them. This could also be the subject of further research.

\section{Acknowledgements}

The result was created in solving the junior project "Possibilities of Supporting Cross-generational Cooperation in the Workplace" using institutional support for long-term conceptual development of research of the University of Finance and Administration. 


\section{Bibliography}

Adamec, V. et al. (2008): Doprava, zdraví a životní prostředí. [Transport, health and environment] Praha: Grada Publishing.

Argo Group (2017). Historie společnosti 2017. [History of company] Retrieved 1. 11. 2021 from http://www.argogroup.cz/skupina-argo/spolecnostive-skupine/csplas/historie-spolecnosti-5.htm

Becker, J., Reimer, E., Rust, A. \& Vogel, K. (2015). Klaus Vogel on Double Taxation Conventions. Wolters Kluwer Law International.

Czech Republic (1974). Smlouva mezi Československou socialistickou republikou a Nizozemským královstvím o zamezení dvojího zdanění a zabráněni daňovému úniku v oboru daně z př́jmu a z majetku. [Convention between the Kingdom of the Netherlands and the Czechoslovak Socialist Republic for the avoidance of double taxation and the prevention of fiscal evasion with respect to taxes on income and capital]

Czech Republic (1992). Zákon č. 586/1992 Sb., o danich z př́ijmi̊, ve znění pozdějších predpisü. [Act No. 586/1992 Coll., on Income Taxes, as later amended]

Czech Republic (2009). Zákon č.280/2009 Sb., daňový rád. [Act No.280/2009 Coll., Tax Code]

General Financial Directorate (2015). Pokyn GFř-D-21 k promíjení př́slušenství daně. [Instruction GFR-D-21 on waiving tax accessories] Praha: GFŘ. Retrieved 1. 11. 2021 from http://www.financnisprava.cz/assets/cs/prilohy/dzakony/Pokyn_GFR_D-21.pdf

General Financial Directorate (2016). Informace ke zdaněni př́ijmů fyzických osob vykonávajícich zaměstnání na palubách lodi či letadel provozovaných v mezinárodni dopravě. [Information on the taxation of income of natural persons employed on board ships or aircraft engaged in international transport] Praha: GF ̌r. Retrieved 1. 11. 2021 from https://archiv.financnisprava.cz/cs/dane/dane/dan-z-prijmu/informacestanoviska-a-sdeleni/2016/zdaneni-prijmu-fo-vykonavajicichzamestn-7538

General Financial Directorate (2017). Informace k možnosti žádat o prominutí př́slušenství daně z př́ijmi ze závislé činnosti vykonávané na palubách lodí a člunů provozovaných ve vnitrozemské a mezinárodni dopravě $v$ Nizozemí. [Information on the possibility of applying for waiving of accessories from income tax on dependent activities performed on board ships and boats operating inland and international transport in the Netherlands] Praha: GFř. Retrieved 1. 11. 2021 from https://archiv.financnisprava.cz/cs/dane/dane/dan-z-prijmu/informace- 
stanoviska-a-sdeleni/2016/informace-k-moznosti-zadat-o-prominutiprislusenstvi-dane-7561

Koroncziová, A. \& Kacaljak, M. (2017). GAAR as tax treaty override: Slovak perspective. DANUBE: Law, Economics and Social Issues Review. 8(3), 139-155

Kurzy.cz (2016). Jednotný kurz v roce 2016-2021, historie kurzů měn. [Uniform exchange rate in 2016-2021), history of currency exchange rates] Retrieved 1. 11. 2021 from http://www.kurzy.cz/kurzymen/jednotny-kurz/

Miller, A., Mulligan, E. \& Oats, L. (2017). Principles of International Taxation. $6^{\text {th }}$ edition. Bloomsbury Publishing.

Minimumloon Nl (2021). Retrieved 1. 11. 2021 from https://www.minimumloon.nl/.

Ministry of Finance (2017). Taxation of Czech boatmen working on board ships in the Netherlands, information on current developments as of 7 July 2017 (internal material for the members of Parliament's Budget Committee for the meeting on 12 July 2017).

Ministry of Finance (2021). List of the Agreements for the elimination of double taxation with respect to taxes on income or with respect to taxes on income and on capital in force. Retrieved 1. 11. 2021 from https://www.mfcr.cz/cs/legislativa/dvoji-zdaneni/prehled-platnychsmluv

Parliament of the Czech Republic (2018). Tisk 80 - změna zákona o daních z prrijmů. [Print 80 - Amendment to the Income Tax Act] Praha: Chamber of Deputies, Parliament of the Czech Republic. Retrieved 1. 11. 2021 https://www.psp.cz/sqw/historie.sqw?o $=8 \& \mathrm{~T}=80$

Slovak Republic (2003). Income Tax Act No. 595/2003 Coll. as later amended. Široký, J. (2018). Daně v Evropské unii. [Taxes in the European Union] $7^{\text {th }}$ updated edition. Praha: Leges, ISBN 978-80-7502-274-5.

Švarc, B., Vanner, L. \& Zídek, K. (1984). Do světa po velkých řekách. [To the world by big rivers] Praha: Nakladatelství dopravy a spojů. ISBN 31011-84-05-102.

Tax Consultants International BV (2019). Dutch tax rates for individuals. Retrieved 1. 11. 2021 from https://www.tax-consultantsinternational.com/read/Dutch_tax_rates_2019_individuals?submenu= $4772 \&$ sublist $=3275 \&$ subsublist $=3300$

The Netherlands (2018). Regeling van de Minister van Sociale Zaken en Werkgelegenheid van 15 november 2017, 2017-0000175287, tot vaststelling van de premiepercentages werknemers- en volksverzekeringen, het maximumpremieloon werknemersverzekeringen en de opslag kinderopvangtoeslag voor 
Czech boatmen employed in the Netherlands: Unusual income taxation ...

2018. Retrieved $1 . \quad 11.2021$ from https://zoek.officielebekendmakingen.nl/stcrt-2017-66804.html 
